\title{
Improvement of Invertase Synthesis by the Mutant Saccharomyces cerevisiae through UV Mutagenesis
}

\author{
S. Saravanan ${ }^{1}$, Abdul Nasar Kalanthoden ${ }^{2}$, R. Karthikayan $^{1}$, M. Kavitha ${ }^{3, *}$, S. Kutti Rani ${ }^{2}$ \\ ${ }^{1}$ School of Life Sciences, B.S. Abdur Rahman Crescent University, India \\ ${ }^{2}$ Department of Chemistry, B.S. Abdur Rahman Crescent University, India \\ ${ }^{3}$ Department of Pharmaceutical Technology, Vinayaka Mission University, India
}

Copyright $\mathrm{O} 2017$ by authors, all rights reserved. Authors agree that this article remains permanently open access under the terms of the Creative Commons Attribution License 4.0 International License

\begin{abstract}
In fermentation technology, strain improvement of baker's yeast has traditionally relied on random mutagenesis followed by screening for mutant exhibiting enhanced properties of interest. Such mutant organisms are useful in several industries. Saccharomyces cerevisiae can use sucrose as the sole source of both carbon and energy; hydrolysis of this sugar is catalyzed by the enzyme invertase. The main objective of this work is to overcome the glucose repression of invertase by invertase

constitutive mutants through UV mutation. This may occur in any glucose repressible genes as a single or double mutation in repressor gene (s) which might cause constitutive synthesis of invertase. These mutated screened strains were optimized with various glucose concentration and different incubation hours for higher invertase production. The maximum synthesis of invertase was 1.066 units $/ \mathrm{ml}$ in hour from mutant Saccharomyces cerevisiae type-2 strain.
\end{abstract}

\section{Graphical Abstract}

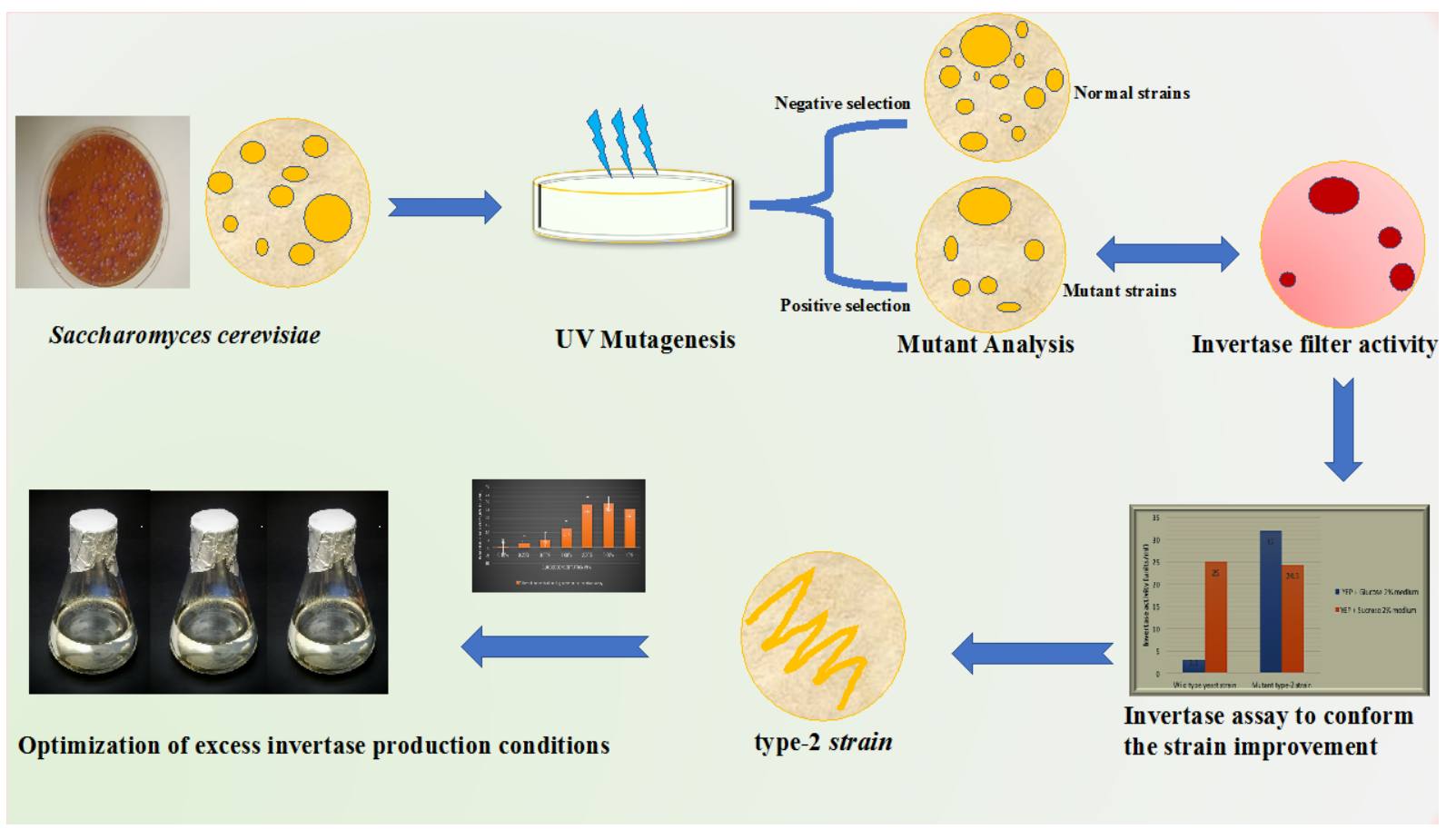


Keywords Constitutive Synthesis, Invertase, Mutation, Optimization, Saccharomyces cerevisiae, UV Mutagenesis

\section{Introduction}

Saccharomyces cerevisiae is the most thoroughly investigated eukaryotic microorganism, which aids our understanding the biology of the eukaryotic cell. For several decades, it has been used in the production of food and alcoholic beverages, and at present it is used in number of different food and pharmaceutical industries. The advantage of using this microorganism is to speed up and reduce the cost of process and to allow continuous production of high-value biomolecules in a subject of great current interest [1].

Invertase is encoded by a family of six unlinked structural genes namely SUC 1 to SUC 5 and SUC 7 are known to exist in this genome [2-6]. Each SUC gene encodes for both a secreted and an intra cellular form of invertase. A specific yeast strain may possess none, one or several functional SUC genes $[7,3]$. The level of enzyme secretion depends on the concentration of glucose in the culture medium [9]. Repression of the external invertase synthesis has been described by the level of transcription [10] and [11], translation, and glycosylation [12] of the protein. $S$. cerevisiae growing under repressible condition $(1 \%$ glucose or more) could produce a burst of external invertase when shifted to higher temperature. The secretion of this invertase requires protein synthesis, but it was found to be independent of RNA formation. The level of accumulated and translated mRNA was inversely proportional to the glucose present in the growth medium [13]. These results are consistent with the hypothesis that invertase is continuously synthesized both in the presence and absence of glucose, but it is degraded under repressible condition [14]. Two types of mutants affected in the regulation of invertase synthesis. Mutation in any of the six snf genes such as snf1, snf2, snf3, snf4, snf5, and snf6 prevents the de-repression of invertase synthesis and thus identifies elements of positive control [15, 16]. Mutation causing constitutive synthesis of invertase, thus defective in negative control (glucose-insensitive) isolated suppressors of snf, which prevents the de-repression of glucose repressible genes. Mutation occurs in one of the suppressor genes, snf6, causes constitutive synthesis of invertase and other repressible enzymes [17]. The snfl gene [18- 20] product is required to depress the expression of many glucose repressible genes including the SUC2 structural gene of invertase [16]. In wild-type strains, synthesis of this mRNA is regulated by glucose repression $[21,22]$. A $1.8 \mathrm{~kb}$ mRNA transcribed constitutively from the SUC2 gene encloses the cytoplasmic invertase, which plays no major role in sucrose fermentation [11]. Mutation causes constitutive synthesis of high level invertase.

An increase in productivity to reduces the overall cost of the product, as well as the production cost; hence, it is one of the important topics for the research. Usually, enhanced productivity can be achieved by strain improvement and optimizing the process parameters [23]. Therefore, random ultraviolet (UV) light mutagenesis of Backer's yeast could be promising strategy for improving invertase productivity [24]. Screening the large number of mutant strain selection by using a direct invertase filter assay method was highly relaying to isolate a higher invertase synthesizing strains [17]. Media optimization, which is still one of the most critically investigated phenomena, is carried out before any large-scale metabolite production. It became more vibrant, effective, efficient, economical and robust in fermentation industry [24]. For designing the most suitable fermentation conditions and appropriate medium components and its percentages must be identified and optimized then only maximum product concentration could be achieved [24].

In this study, we attempted to improve the invertase productivity of the wild type yeast by UV mutagenesis. First, wild type baker's yeast was irradiated by UV and then mutant strains were selected based on invertase filter assay method. Then, screened strains were conformed the glucose repression of invertase constitutive mutants. Finally, optimize the fermentation conditions for the excess production of invertase by isolated mutant $\mathrm{S}$. cerevisiae strain was deliberate.

\section{Materials and Methods}

\subsection{Chemicals}

Baker's yeast was obtained from a ("saf-instant red" commercially available) local market. All chemicals were analytical grade purchased from Sigma-Aldrich and Merck.

\subsection{Screening of High Sucrose Fermenting Yeast Strain}

Wild type baker's yeast $0.5 \mathrm{gm}$ was dissolved in $10 \mathrm{ml}$ of $0.1 \mathrm{M}$ phosphate buffer then $0.1 \mathrm{ml}$ of suspended yeast was spread on YEPD (Yeast extract peptone dextrose) agar medium $[25,26]$ containing $10 \mathrm{gm}$ of yeast extract, $20 \mathrm{gm}$ of peptone, $20 \mathrm{gm}$ of dextrose, and agar adjusted to $\mathrm{pH} 7.2$ in $1000 \mathrm{ml}$ of distilled water along with streptomycin (100 $\mu \mathrm{g} / \mathrm{ml})$ and ampicillin $(50 \mu \mathrm{g} / \mathrm{ml})$ containing plates incubated at $30^{\circ} \mathrm{C}$ for $30 \mathrm{~h}$ and slants its used for further studies. For isolated pure strains ware inoculated on YEPS (Yeast extract peptone sucrose) agar medium containing $10 \mathrm{gm}$ of yeast extract, $20 \mathrm{gm}$ of peptone, $20 \mathrm{gm}$ of sucrose, and agar was adjusted to $\mathrm{pH} 7.2$ in $1000 \mathrm{ml}$ of distilled water containing bromocresol purple as an indicator which was used to screen yeast capable of high sucrose fermenting.

\subsection{UV Mutagenesis, Mutation Analysis and Strain Selection}

Isolated culture inoculated in YEPD $(50 \mathrm{ml})$ medium, as 
described previously. After the incubation cells were harvested at $5000 \mathrm{rpm}$ for $10 \mathrm{~min}$. The pellet was washed twice with $0.1 \mathrm{M}$ phosphate buffer $(\mathrm{pH} 7.0)$ and the harvested cells were suspended in $10 \mathrm{ml}$ of $0.1 \mathrm{M}$ phosphate buffer $(\mathrm{pH}$ 7.0), then $1 \mathrm{ml}$ of the suspended cells were aliquoted in to sterilized glass petri plates, along with $5 \mathrm{ml}$ of phosphate buffer ( $\mathrm{pH} 7.0)$. The aliquots were exposed to UV radiation for varying time intervals $(0,5,10,20$ and $30 \mathrm{~min})$ to provide varying $\mathrm{UV}$ dosage under the laminar flow hood and UV source for $48 \mathrm{~cm} .100 \mu \mathrm{l}$ of each sample were used to spread on YEP glucose plates and incubated at $30^{\circ} \mathrm{C}$ for $30 \mathrm{~h}$ then analysis of mutation frequency [27] and survival rate percentages to be calculated by widely used Luria and Delbruck method [28].

\subsection{Filter Assay of Invertase Activity}

This technique was used to screen large numbers of mutants, for detecting invertase activity in yeast grown in glucose medium [17]. Mutant yeast colonies grown in YEP glucose on agar plates were transferred to dry whatman no. 3 filters $(9 \mathrm{~cm}$ diameter) by pressing the filters on to the plates. A second dry filter was stapled to the first filter to make a sandwich with yeast colonies in between. The filter sandwich was placed in $100 \mathrm{ml}$ of distilled water to remove any glucose or other reducing sugars. The filters were then wetted with a solution containing $5 \%$ sucrose in $10 \mathrm{~mm}$ sodium acetate buffer $(\mathrm{pH}$ 4.6) and incubated at room temperature for 3 to $5 \mathrm{~min}$ and transferred to a separate petri dish floating in a $50^{\circ} \mathrm{C}$ water bath. A portion $(3 \mathrm{ml})$ of $0.1 \%$ triphenyl tetrazolium chloride in $0.5 \mathrm{~N}$ sodium hydroxide was added. The red color spots indicate the invertase positive colonies through mutation ( 1 to $2 \mathrm{~min}$ ). The filters were removed, dried, and stored in refrigerator.

\subsection{Invertase Assay}

Invertase assay was performed by Nelson-Somagy's method [29], $1 \mathrm{mg} / \mathrm{ml}$ of standard glucose stock solution was prepared. From this, different concentrations (10, 20, 30, 40, and $100 \mu \mathrm{g} / \mathrm{ml}$ ) of standard glucose solution were prepared and final volume was adjusted to $2 \mathrm{ml}$ using buffer, (Table 1) vortexed and measured at $520 \mathrm{~nm}$. A standard graph was drawn based on the data obtained (absorbance vs concentration). Invertase assay was carried out to compare the enzymatic activity of wild type and mutant type- 1 to type-4 yeasts. All strains were grown on YEP+glucose and YEP+sucrose medium for $30 \mathrm{~h}$ at room temperature, respectively. After incubation, the culture was centrifuged at $5000 \mathrm{rpm}$ for $10 \mathrm{~min}$. Then the supernatant was carefully collected and stored. $50 \mu \mathrm{l}$ of the culture supernatant was used for invertase assay.

$2 \mathrm{ml}$ of $0.1 \mathrm{M}$ sodium acetate buffer $(\mathrm{pH} 4.5), 0.5 \mathrm{ml}$ of $0.1 \mathrm{M}$ substrate and $50 \mu \mathrm{l}$ of culture supernatant mixtures were incubated at $37^{\circ} \mathrm{C}$ in a water bath for exactly $15 \mathrm{~min}$, and color intensity was measured at $520 \mathrm{~nm} .2 \mathrm{ml}$ of $0.1 \mathrm{M}$ sodium acetate buffer used as blank, without invertase as substrate blank and without substrate as enzyme blank used for invertase assay.

Protein concentration in enzyme sample was estimated by Bradford's [30] method using bovine serum albumin (BSA) as a standard. To prepare standard BSA, $1 \mathrm{mg} / \mathrm{ml}$ of BSA stock solution was prepared using distilled water and the concentration starting from 0 to $100 \mu \mathrm{g}$. The final volume was made up to $500 \mu \mathrm{l}$ with distilled water. The experiment was done in triplicates. $4.5 \mathrm{ml}$ of Bradford reagent was added, mixed, and measured at $590 \mathrm{~nm}$. The data were plotted in a graph as concentration of BSA versus absorbance at $590 \mathrm{~nm}$. One unit enzyme invertase activity is defined as the amount of enzyme, which liberates one micromole of reducing sugar per minute under the condition of the assay. Specific activity is expressed in Units/mg of protein [31].

\subsection{Invertase Assay for Wild and Mutant Yeast}

All subsequent experiments carried out with the initial inoculum yeast cell count approximately $10 \mathrm{CFU} / \mathrm{ml}$. Isolated mutant strains type-1, type-2, type-3, type- 4 and wild type strain $1 \mathrm{ml}$ culture inoculated individually in $50 \mathrm{ml}$ of the YEP glucose and YEP sucrose medium for incubate at $30^{\circ} \mathrm{C}$ for $30 \mathrm{~h}$. After incubation, all the strains invertase enzyme activity estimated according to the previously described methods.

Table 1. Reaction mixtures for invertase assay

\begin{tabular}{|c|c|c|c|c|c|}
\hline \multirow{2}{*}{ Components } & \multirow{2}{*}{ Blank } & \multirow{2}{*}{ Substrate Blank } & \multirow{2}{*}{ Enzyme Blank } & \multicolumn{2}{|c|}{ Test Sample Growth } \\
\hline & & & & Sucrose & Glucose \\
\hline $0.1 \mathrm{M}$ sodium acetate buffer $(\mathrm{pH} 4.5$ ) & $2 \mathrm{ml}$ & $1.5 \mathrm{ml}$ & $1.5 \mathrm{ml}$ & $1.5 \mathrm{ml}$ & $1.5 \mathrm{ml}$ \\
\hline $0.1 \mathrm{M}$ substrate & 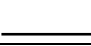 & $0.5 \mathrm{ml}$ & 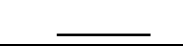 & $0.5 \mathrm{ml}$ & $0.5 \mathrm{ml}$ \\
\hline $1 \mathrm{mg} / \mathrm{ml}$ invertase & 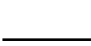 & 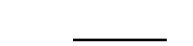 & $50 \mu \mathrm{l}$ & $50 \mu 1$ & $50 \mu \mathrm{l}$ \\
\hline Total & $2 \mathrm{ml}$ & $2 \mathrm{ml}$ & $2 \mathrm{ml}$ & $2 \mathrm{ml}$ & $2 \mathrm{ml}$ \\
\hline
\end{tabular}




\subsection{Optimization of Invertase Production}

\subsubsection{Effect of Various Concentration of Glucose}

Mutant strain type-2 ware inoculated separately to different concentrations $(0.1,0.2,0.5,1.0,2.0,5.0$, and $10 \%)$ of glucose in YEP broth. Then it was incubated $30^{\circ} \mathrm{C}$ for $30 \mathrm{~h}$ and then invertase activity was assayed as described above method.

\subsubsection{Effect of Various Incubation Periods}

The type-2 mutant yeast culture was inoculated in $50 \mathrm{ml}$ YEP glucose broth and kept for $30^{\circ} \mathrm{C}$ for incubation at various time intervals such as $10,20,30,40,50$, and $60 \mathrm{~h}$. After incubation, the culture was assayed for the invertase activity.

\subsubsection{Statistical Analysis}

All data point represents the mean of three independent assays. Statistical implication was determined by standard deviation. The data are represented as the mean \pm standard error (Figures 1-5).

\section{Results and Discussion}

After incubation, large white colonies of yeast cells were observed and change of color from purple to yellow around the colonies as indicator for sucrose fermentation. This isolated single colony was named as wild type strain and sub cultured in YEPD medium along with streptomycin 100 $\mu \mathrm{g} / \mathrm{ml}$ and ampicillin $50 \mu \mathrm{g} / \mathrm{ml}$ containing plates for further screening studies.

High invertase producing mutants were selected from UV mutation and invertase filter paper assay. In filter paper assay, red color spots were developed in the filter paper indicating the positive colonies of invertase. [17], previously reported the same results. This indicates the ability of the mutated culture to produce invertase in YEP glucose medium. This red color spotted colonies were positive selection for further subculture. Based on UV exposure time, type-1, type-2, type-3, and type-4 mutant strains derived from wildtype strain. As shown to the Table 2, approximately $100 \%$ survival rate, $1 * 10^{7}$ mutation frequency and no more invertase positive colonies on wild type strain but type-1 strain have 15 invertase positive colonies with $15^{*} 10^{-8}$ mutation frequency and their survival rate also high $85.5 \%$ compare to other mutant. In type- 4 strain $42.8 \%$ survival rate with $3 * 10^{-8}$ mutation frequency and lower invertase positive colonies compare to other mutant; type- 2 have 5 and type- 3 have 4 positive colonies. As per the Fig. 1 wild type strain survival rate of percentage ware gradually degreases from $100 \%$ to $42.8 \%$ this comparable report previously reported [32] but the time of exposure was in seconds. More than 30 mins exposure are usually lethal for yeast in their reproduction. But, this isolated strains actively grown in subsequent cultures However, all the mutant strains having significant mutation frequency and invertase positive colonies on filter paper assay, these results Table 2 and Fig 1 shown initial evaluation of mutant strains.

Table 2. Generation of mutant strains by UV mutagenesis and mutation analysis of wild type baker's yeast.

\begin{tabular}{|c|c|c|c|c|}
\hline UV Exposure time(min) & Strains & Survival rate \% & $\begin{array}{c}\text { Mutation } \\
\text { frequency }\end{array}$ & $\begin{array}{c}\text { Number of invertase positive colonies } \\
\text { (Invertase filter assay) }\end{array}$ \\
\hline 0 & wild type & 100 & $1 * 10^{7}$ & - \\
\hline 5 & type-1 & 85.5 & $15^{*} 10^{-8}$ & 5 \\
\hline 10 & type-2 & 78.5 & $5 * 10^{-8}$ & 4 \\
\hline 20 & type-3 & 68.2 & $4 * 10^{-8}$ & 3 \\
\hline 30 & type-4 & 42.8 & $3 * 10^{-8}$ & 5 \\
\hline
\end{tabular}

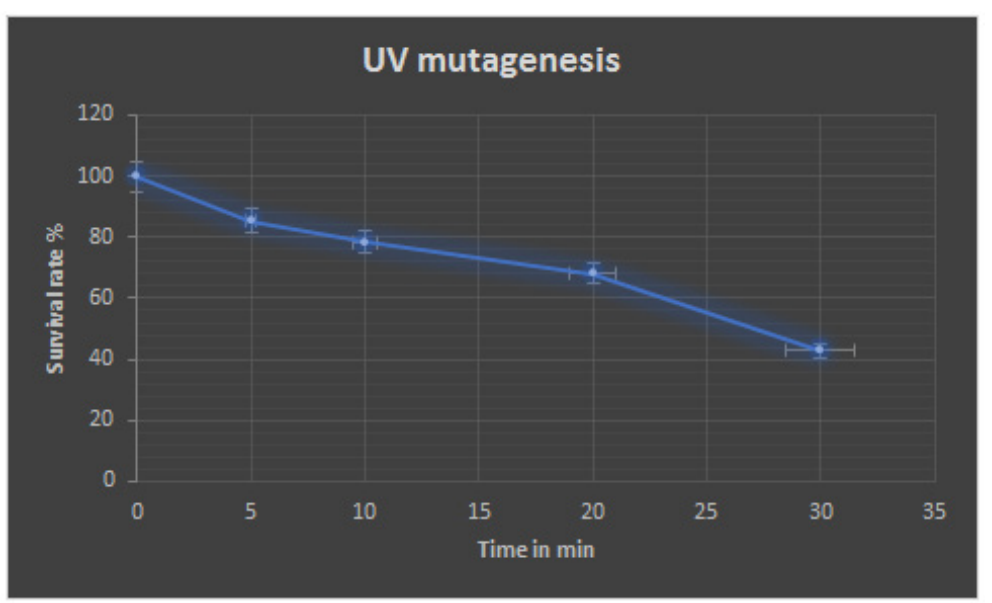

Figure 1. UV radiation mutagenesis survival rate $\%$ of wild type strain. For the analysis of survival rates by UV mutagenesis, cells grown for $24 \mathrm{~h}$ at $30^{\circ} \mathrm{C}$ on a YPD medium plate were collected and suspended in phosphate buffer. After the cell concentration was determined by counting, cells were spread on YPD medium plates. The plates were placed under a UV lamp at a distance of $48 \mathrm{~cm}$ and were irradiated for various periods of time. Following irradiation, the plates were incubated at $30^{\circ} \mathrm{C}$ for $30 \mathrm{~h}$, and the numbers of colonies were counted to determine survival rates. 


\subsection{Invertase Assay for Wild and Mutant Yeast}

Isolated mutant strains and wild type yeast cells were grown in YEP glucose and YEP sucrose medium for invertase assay (Fig 2) to compare their invertase synthesis ability. In wildtype yeast invertase activities in glucose, sucrose was 3.1, and 25.0 Units/ml, respectively. Although in mutant strain type-1 very less 20.2 Units $/ \mathrm{ml}$ in sucrose medium. In type-3 highest $28.4 \mathrm{Units} / \mathrm{ml}$ in sucrose, but lowermost in glucose medium 1.2 Units $/ \mathrm{ml}$. comparably type-4 not much improvement in mutagenesis almost similar observations as wild type strain 3.4, and 22.8 Units $/ \mathrm{ml}$. Ultimately type- 2 strain in glucose medium was progressively increased from 3.1 to $32.0 \mathrm{Units} / \mathrm{ml}$ and almost near $24.1 \mathrm{Units} / \mathrm{ml}$ in sucrose medium as compared to the wild type. Therefore, mutant type- 2 strain was assumed as could be a constitutive mutant for the production of invertase (Table 3-4, Fig 2). This mutation may have occurred in any glucose repressible genes such as SSn, snf1, snf3, snf4, snf6, and including the SUC2 structural gene [11], [33], [34]. This single or double mutant leads to de-repress the repressible gene [20]. Unfluctuating outcomes in hourly invertase synthesis increased from 0.103 to $1.066 \mathrm{UNITS} / \mathrm{ml}$ in glucose medium and almost similar 0.833 and 0.803 Units $/ \mathrm{ml}$ in sucrose medium as compared to the wild type (Fig 3). Its accord this mutation causes constitutive synthesis of invertase and overcome the glucose repression of the secreted invertase through mutation.
Table 3. Invertase assay of wild type yeast

\begin{tabular}{|c|c|c|}
\hline & $\begin{array}{c}\text { YEP + Glucose 2\% } \\
\text { medium }\end{array}$ & $\begin{array}{c}\text { YEP + Sucrose } \\
\mathbf{2 \%} \text { medium }\end{array}$ \\
\hline Substrate blank (OD) & 0.29 & 0.29 \\
\hline Enzyme blank (OD) & 0.07 & 0.07 \\
\hline Test solution (OD) & 0.56 & 1.98 \\
\hline Net reading (OD) & 0.20 & 1.62 \\
\hline $\begin{array}{c}\text { Enzyme activity } \\
\text { (Units/ml) }\end{array}$ & 3.1 & 25.0 \\
\hline Total protein (m) & 3.9 & 11.0 \\
\hline $\begin{array}{c}\text { Specific activity } \\
\text { (Units/mg) }\end{array}$ & 0.79 & 2.27 \\
\hline
\end{tabular}

*OD- optical density

Table 4. Invertase assay of mutant type-2 yeast

\begin{tabular}{|c|c|c|}
\hline & $\begin{array}{c}\text { YEP + Glucose 2\% } \\
\text { medium }\end{array}$ & $\begin{array}{c}\text { YEP + Sucrose } \\
\mathbf{2 \%} \text { medium }\end{array}$ \\
\hline Substrate blank (OD) & 0.32 & 0.32 \\
\hline Enzyme blank (OD) & 0.09 & 0.09 \\
\hline Test solution (OD) & 2.44 & 1.98 \\
\hline Net reading (OD) & 2.04 & 1.56 \\
\hline $\begin{array}{c}\text { Enzyme activity } \\
\text { (Units/ml) }\end{array}$ & 32.0 & 24.3 \\
\hline Total protein (mg) & 15.0 & 11.6 \\
\hline $\begin{array}{c}\text { Specific activity } \\
\text { (Units/mg) }\end{array}$ & 2.10 & 2.09 \\
\hline
\end{tabular}

Net glucose $=$ Test solution - Enzyme blank

O.D O.D

Net reading $=$ Net glucose - substrate blank O.D O.D

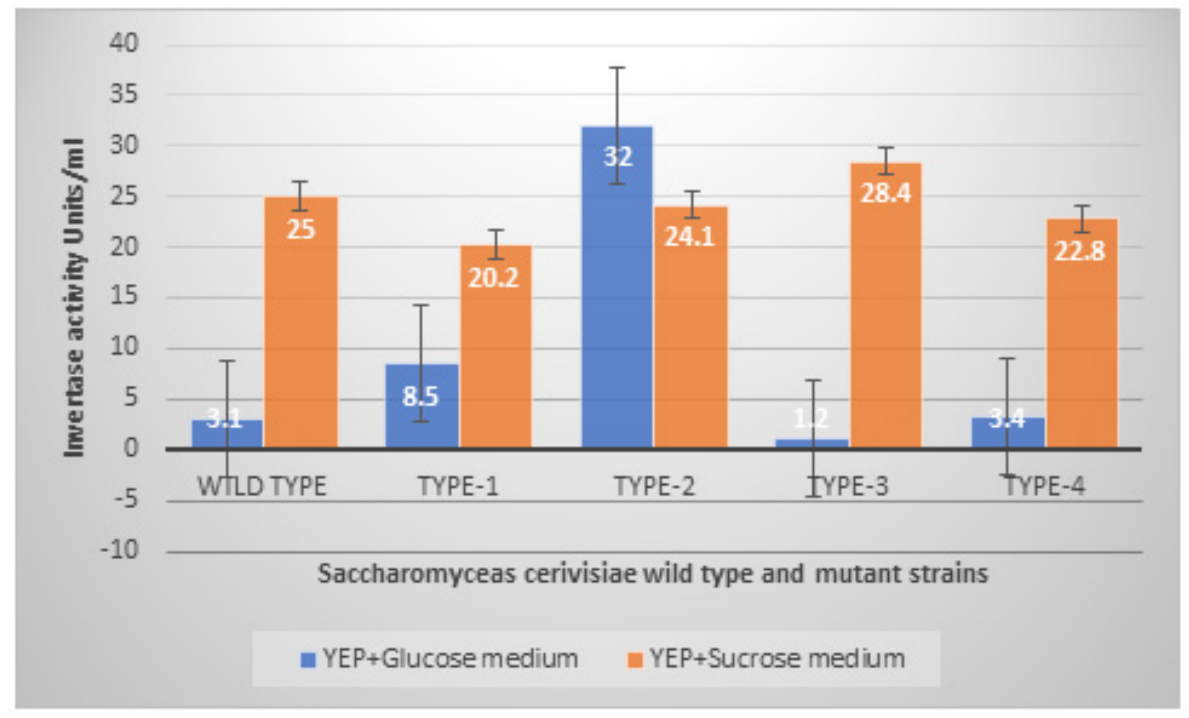

Figure 2. Invertase activity of Saccharomyces cerevisiae wild type and mutant strains 


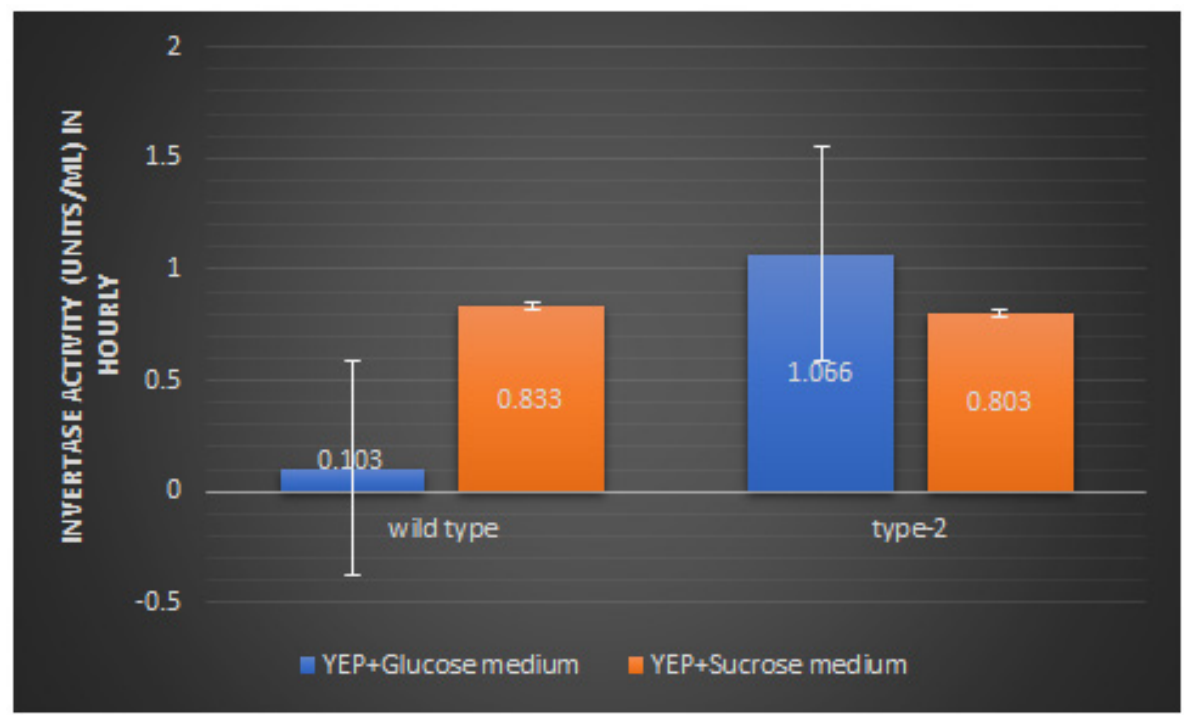

Figure 3. Invertase activity in hourly for wild and mutant type-2 yeast strain

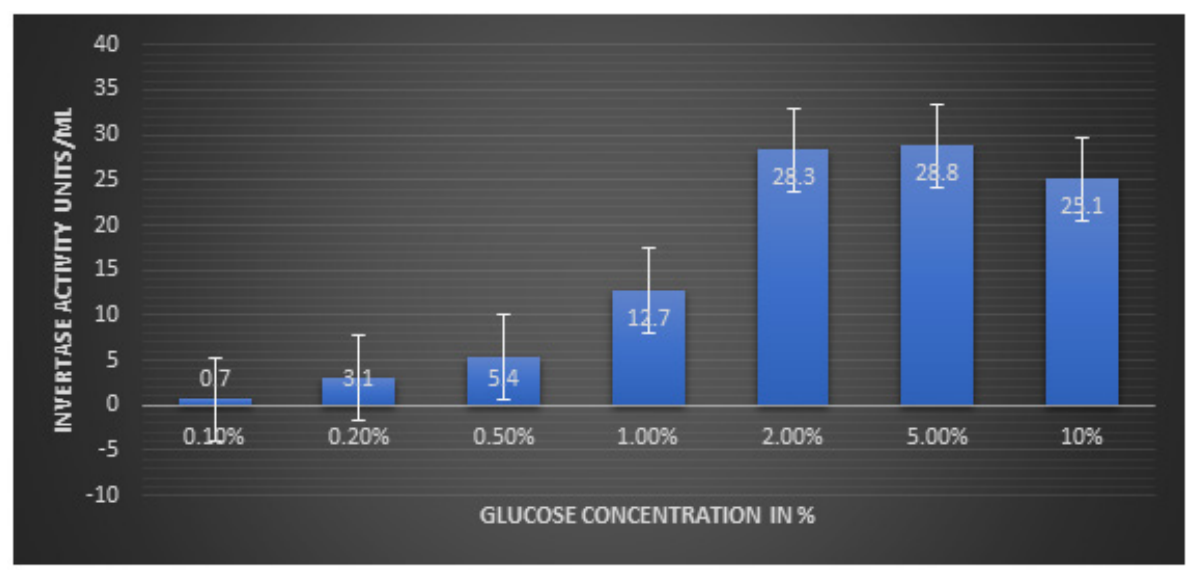

Figure 4. Different glucose concentrations in mutant type-2 growth medium for invertase assay

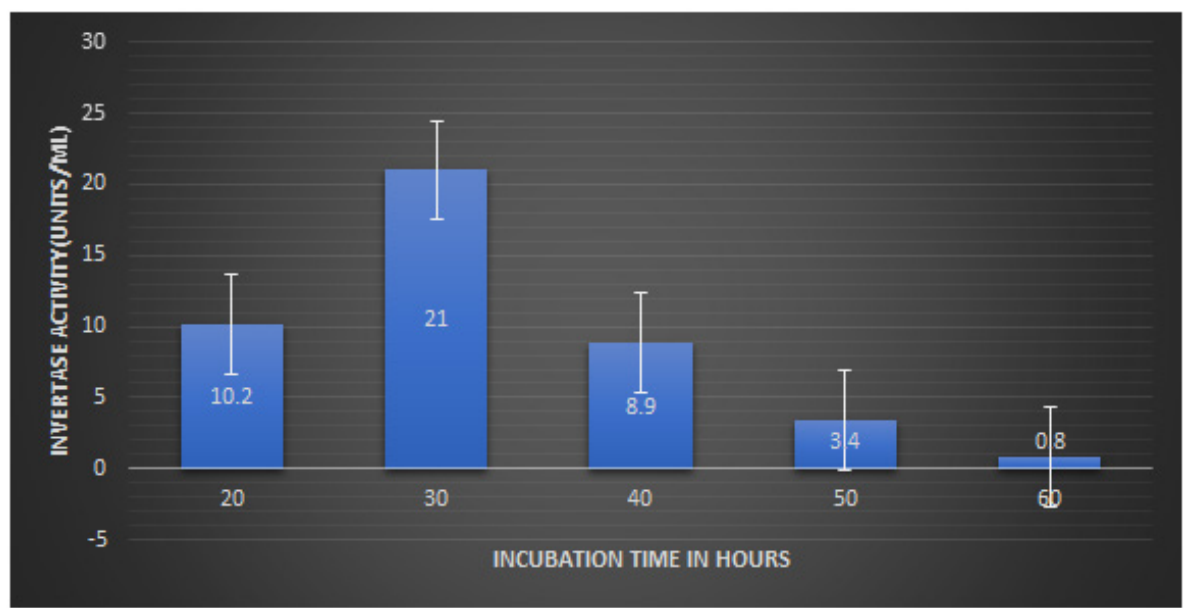

Figure 5. Different incubation periods for mutant type-2 strain for the invertase assay.

The effect of glucose concentration $(0.1,0.2,0.5,1.0,2.0$, enzyme activity was almost reduced in 10\% (Fig: 4). In 5.0 , and $10 \%)$ and incubation duration time $(10,20,30,40$, 50 , and $60 \mathrm{~h}$ ) was tested on mutant type-2 strain. The highest invertase production was observed at $2 \%(28.3 \mathrm{Units} / \mathrm{ml})$ and at $5 \%$ (28.8 Units $/ \mathrm{ml})$ of glucose. Beyond $5 \%$ glucose, the different invertase production time duration experiment, the maximum enzyme activity was observed at $30 \mathrm{~h}(21.0$ Units/ml) of incubation. Further increase in the incubation time significantly reduces the invertase activity its shown in 
Fig:5 Similar observation has been reported previously with $\mathrm{pH}$ 3.5-5.0 [35] and optimum temperature $70^{\circ} \mathrm{C}$ [36] observation also reported.

In conclusion, this work is to overcome the glucose repression of the secreted invertase through traditional UV mutation. This mutational effort has given an industrially potent strain and the above conditions are valuable for the excess production of invertase to speed up the industrial processes. Further studies of genetic engineering, pathway analysis, transcriptome, and proteome analysis are needed to improve more economical and biologically safer products in the fermentation industry.

\section{Conflict of Interest}

The authors declare that they have no conflict of interest in the publication.

\section{REFERENCES}

[1] Eduardo JS Brás et al, A microfluidic platform for physical entrapment of yeast cells with continuous production of invertase, Journal of chemical Technology and Biotechnology, 2016

[2] Del Castillo Agudo, L and Zimmermann,F.K.: Novel genetic components controlling invertase production in Saccharomyces cerevisiae. J. Gen. Microbiol. 133 (1987)

[3] Hohmann, S.and Gozalbo, D.: Structural analysis of the 5' region of yeast SUC genes revealed analogous palindromes in SUC, MAL and GAL, Mol. Gen. Genet. 211 (1988).

[4] Parets Soler, A.: Base substitutions in the 5' noncoding regions of two naturally occurring yeast invertase structural SUC genes cause strong differences in specific invertase activities. Curr. Gent. 15 (1989)

[5] Carlson, M. and Botstein, D.: Organization of the SUC gene family in Saccharomyces. Mol. Cell. Biol. 3 (1983)

[6] Carlson, M., Osmand, B. C. \& Botstein, D. (1981): Genetic evidence for a silent SUC gene in yeast. Genetic 98

[7] Grossmann, M.K. and Zimmermann F.k.: The structural genes of internal invertase in Saccharomyces cerevisiae. Mol. Gen. Genet. 175 (1979)

[8] Sarokin, L. and Carlson, M.: Comparison of two yeast invertase genes: conservation of the upstream regulatory region. Nucleic Acids Res. 13 (1985)

[9] Gascon, S., and P. Ottalenghi. 1972: Influence of glucose concentration of the medium on the invertase content of a strain of Saccharomyces bearing the SUC2 gene. C. R. Trav. Lab. Carlsberg 39

[10] Elorza, M. V., J. R. Villanueva, and Sentandreu. 1977: The mechanism of catabolite inhibition of invertase by glucose in Saccharomyces cerevisiae. Biochim. Biophys. Acta 475
[11] Perlmann, D., and H.O. Halvorson. 1981: a single gene encodes distinct repressible mRNAs for cytoplasmic and secreted yeast invertase. Cell 25

[12] Chu, F.K., and F. Maley. 1980: The effect of glucose on the synthesis and glycosylation of the polypeptide moiety of yeast external invertase. J. Biol. Chenn 255

[13] Zimmermann, F.K., and I. Scheel. 1977: Mutants of S. cerevisiae Resistant to carbon catabolite repression. Mol. Gen. Genet. 154: 75 - 82.

[14] Carlson, M., and D. Botstein, 1982: Two differentially regulated mRNA with different 5 ' ends encode secreted and intracellular forms of yeast invertase. Cell 28

[15] Celenza, J. L. and M. Carlson, 1984b: Structure and expression of the SNF1 gene of Saccharomyces cerevisiae. Mol. Cell. Biol.

[16] Carlson, M., B.C. Osmand, L. Neigeborn and D. Botstein, 1984: A suppressor of snfl mutation causes constitutive high-level invertase synthesis in yeast. Genetic 107

[17] Trumbly, R. J., 1986: Isolation of Saccharomyces cerevisiae mutants constitutive for invertase synthesis. J. Bacteriol. 166

[18] Celenza, J. L. and M.Carlson, 1984b: Structure and expression of the SNF1 gene of Saccharomyces cerevisiae. Mol. Cell. Biol.

[19] Neigeborn, L., and M. Carlson, 1987: Genes affecting the regulation of SUC2 gene repression by glucose repression in Saccharomyces cerevisiae. Genetics 108

[20] Neigeborn, L., K. and M. Carlson, 1987: Mutation causing constitutive invertase synthesis in yeast: genetic interactions with snf mutation. Genetic 115

[21] Carlson, M., and D. Botstein, 1982: Two differentially regulated mRNA with different 5 ' ends encode secreted and intracellular forms of yeast invertase. Cell 28

[22] Chu, F.K., and F.Maley. 1980: The effect of glucose on the synthesis and glycosylation of the polypeptide moiety of yeast external invertase. J. Biol. Chenn 255

[23] Singh V, Haque S, Niwas R, Srivastava A, Pasupuleti M and Tripathi CKM (2017) Strategies for Fermentation Medium Optimization: An In-Depth Review. Front. Microbiol. 7:2087

[24] Yamada, R., Kashihara, T. \& Ogino, H. Improvement of lipid production by the oleaginous yeast Rhodosporidium toruloides through UV mutagenesis. World J Microbiol Biotechnol (2017) 33: 99

[25] Aleksandra M \& Zoran (2017) Comparative study of stability of soluble and cell wall invertase from Saccharomyces cerevisiae, Preparative Biochemistry and Biotechnology, 47:3, 305-311

[26] Andjelkovic, U.; Picuric, S.; Vujcic, Z. Purification and Characterisation of Saccharomyces cerevisiae External Invertase Isoforms. Food Chem. 2010, 120(3), 799-804

[27] Rosche, W., and P. Foster. 2000. Determining mutation rates in bacterial populations. Methods 20: 4-17.

[28] Luria, Salvador E., and Max Delbrück. "Mutations of bacteria from virus sensitivity to virus resistance." Genetics 28.6 (1943): 491. 
[29] N Nelson - Journal of biological chemistry, 1944 A photometric adaptation of the Somogyi method for the determination of glucose

[30] Bradford, M. M. 1976: A rapid and sensitive method for quantitation of microgram quantities of protein utilizing the principle of protein-dye binding. Anal. Biochem. 72

[31] Palanivalu .P: Separation techniques. Analytic biochemistry and reparation techniques $2^{\text {nd }}(2001) 142-159$.

[32] Hashimoto, S., Ogura, M., Aritomi, K., Hoshida, H., Nishizawa, Y., \& Akada, R. (2005). Isolation of Auxotrophic Mutants of Diploid Industrial Yeast Strains after UV Mutagenesis. Applied and Environmental Microbiology, 71(1), 312-319
[33] Carlson, M., B.C. Osmand, L. Neigeborn and D. Botstein, 1984: A suppressor of snf1 mutation causes constitutive high-level invertase synthesis in yeast. Genetic 107

[34] Carlson, M., R. Taussig, S. Kustu and D. Botstein, 1983: The secreted form of invertase in Saccharomyces cerevisiae is synthesized from mRNA encoding a signal sequence. Mol. Cell, Biol, 3

[35] Andjelkovic, U.; Picuric, S.; Vujcic, Z. Purification and Characterisation of Saccharomyces cerevisiae External Invertase Isoforms. Food Chem. 2010, 120(3), 799-804.

[36] da Silva, A.R.; Tomotani, E.J.; Vitolo, M. Invertase, Glucose Oxidase and Catalase for Converting Sucrose to Fructose and Gluconic Acid Through Batch and Membrane-continuous Reactors. Braz. J. Pharm. Sci. 2011, 47(2), 399-407 